\title{
EFFICIENT UTILIZATION OF CORN STALK AND POPLAR PLANER SHAVINGS IN MANUFACTURING PARTICLEBOARD
}

\author{
Aree Adel Abdulqader ${ }^{1, \$}$ \\ https://orcid.org/0000-0002-0656-3221
}

\begin{abstract}
In this study, particleboards were manufactured using a mixture of corn stalks and poplar wood particles at different ratios utilizing $10 \%$ urea-formaldehyde adhesive. Panels with a density of $0,70 \mathrm{~g} / \mathrm{cm}^{3}$ were manufactured using various amount of corn stalks and poplar wood from 100 to $25 \%$. Manufactured panels were tested the mechanical properties including modulus of rupture, modulus of elasticity and internal bond and the water absorption and thickness swelling. In addition, the chemical properties and fiber dimensions of poplar wood and corn stalks were also evaluated. Some properties of the manufactured panels increased with the content of poplar particles. The addition of wood poplar particles resulted in a significant increase of some properties of particleboards. From this study, it can be concluded that the combination of poplar particles and corn stalks resulted in particleboards acceptable for interior applications due to low water absorption and thickness swelling. The internal bond strength, the most serious deficiency of stalks, was upgraded sufficiently by increasing the content of wood poplar particles. This study demonstrate that corn stalks may be considered as a charger for wood poplar particleboards manufacturer in region where wood is not abundant. unusual to wood material in the production of particleboards.
\end{abstract}

Keywords: Mechanical properties, particleboard, physical properties, Populus nigra, Zea mays indurata.

\section{INTRODUCTION}

Particleboard is an important product of the composite industry and is manufactured from the wood particles. The world demand for wood composite production is increased with the growing of the world population and the expansion uses of applications that have major impact on resources of standing forest and the supply of wood for production of particleboards has been reduced due to the deforestation of natural forests (Nath and Mwchahary 2012). Increasing world demand contributes to the search of new raw materials of the manufacture of forest products or most efficient use of available raw material. Agricultural residues are renewable annually and abundant therefore became an excellent alternative source that can be used to replace wood and wood fibers if performance is acceptable (Rowell 1995, Nemli et al. 2009). The use of renewable biomass as a raw material can gain the environment and socioeconomic development as these residue materials are grown in the soil and often disposed through combustion with generation of undesirable volatile organic carbon-based products (Rowell 1995, Suleiman et al. 2013).

Several scientists have investigated reported on the characteristics of agrofibers. For decades literature cited and described particleboard manufactured using agricultural wastes and/or residues of annual plants such as; corn pith and wheat straws (Wang and Sun 2002) sunflower stalks (Bektas et al. 2005) kenaf stalks (Kalaycioglu and Nemli 2006) bamboo (Biswas et al. 2011) rice straw (Zhang and Hu 2014). Fibrous materials including straws were used for paper manufacturing about two centuries ago. 
Corn demand has been increased throughout the years to satisfy human consumption resulting in important lignocelluloses residues which could be utilized as raw material to manufacture particleboard and papers They are cheap, ready available, renewable lignocellulosic source, biodegradable from nature, excellent source of cellulose, hemicellulose and lignin and good fibers structure in terms of length and diameter (Azubuike et al. 2012). It is reported that hemicellulose content is higher and the lignin content lower in straw and stalks materials (Rowell et al. 2000, Guler et al. 2016). The morphological evaluation of straw and stalks revealed a higher content of nonfibrous thin wall cells, epidermal cells and parenchyma cells compared to that in wood particles (Liu et al. 2005).

Studies researches have been conducted on the uses of corn stalks in the production of composites (Guler et al. 2016), As Prasetiyo et al. (2019) and they reported that of particleboards made using corn stalk raw materials and urea formaldehyde or phenol formaldehyde was satisfactory. Quality varies with the level of resin uses.

In Kurdistan, corn, wheat, sunflower, rice and other crops are produced for food industries and vegetable oil production resulting in important fiber and residues available. These agriculture residues are used for heat production, animal feedstocks or fertilizers with little economic impact for the growers. Alternatives uses to add value on stalk residues will be beneficiary for the environment by production of VOC (volatile organic compounds) and a good source of income for a good and durable local economy.

The objective of this paper is to examine the feasibility of utilizing corn stalks grown and harvested in Kurdistan combined with local wood mills residues such as wood poplar in the manufacturing of particleboards for construction in interior application when moisture is not a threat. Particleboard will be laboratory manufacture using a combination of straws and wood poplar. Some physical, mechanical and chemical properties will be evaluated and compare to existing standards.

\section{MATERIALS AND METHODS}

In this study poplar wood (Populus nigra) and corn stalks (Zea mays indurata Sturt.) were utilized as a raw material for production of particleboard. Corn stalks were harvested from plantation fields in (Barderesh $\backslash$ Duhok Provence). Straws and debris were separated. Dust and dirt were removed by water washing then chipped coarsely using a chipper machine and a ring flaker to produce small pieces of particles poplar wood particles were collected from a local mill located in Karzan Duhok province of Iraq.

Wood particles were dried and screened through a vibrated sieve. The mean particles size used in this study was $1,5 \mathrm{~cm}$ to $2 \mathrm{~cm}$. screened selected particles were dried at $100{ }^{\circ} \mathrm{C}-105^{\circ} \mathrm{C}$ in an oven a moisture content of $3 \%$ was reached. Table 1 contains the properties of urea-formaldehyde (UF) used in this UF was sprayed using a rotary drum blender equipped with a spray nozzle. the boards were manufactured at density of $0,70 \mathrm{~g} /$ $\mathrm{cm}^{3}$ using with $10 \%$ resin based on the oven dry weight of the materials. About $1 \%$ of ammonium chloride $\left(\mathrm{NH}_{4} \mathrm{CL}\right)$ as hardener was added to urea-formaldehyde resin through blender before spraying on the raw materials. The composition of raw materials in terms of ratio of wood to corn stalk are listed in Table 2. Materials were blended for 3 minutes with the resin and hardener for a better distribution on the particles. coated particles were weighted and placed in a wooden mold measuring ( $36 \mathrm{~cm}$ x $36 \mathrm{~cm}$ x $25 \mathrm{~cm}$ depth) on a $2 \mathrm{~mm}$ steel plate compressed manually after it was covered with an aluminum foil (Archanowicz et al. 2013).

Two experimental particleboards with dimensions of $31 \mathrm{~cm} \times 31 \mathrm{~cm} \times 1 \mathrm{~cm}$ were produced for each design. Boards were pressed at $25 \mathrm{MPa}$ down to $10 \mathrm{~mm}$ at $150{ }^{\circ} \mathrm{C}$ for 10 minutes using a hydraulic press (AS METAL - Ayhan Necipoglu, model SSP - 140). At the end of the pressure cycle, boards were conditioned at $28^{\circ} \mathrm{C}$ and $45 \%$ relative humidity, panels were put in conditioning room until the panels reached the moisture content at $(10 \%)$. After conditioning the boards were edge trimmed to $300 \mathrm{~mm} \times 300 \mathrm{~mm} \times 10 \mathrm{~mm}$. 
Table 1: The properties of urea-formaldehyde (UF) adhesive used in this study.

\begin{tabular}{|c|c|}
\hline Properties & Value \\
\hline Solid content $\%$ & $55 \pm 1$ \\
\hline Density $\left(\mathrm{g} / \mathrm{cm}^{3}\right)$ & 1,22 \\
\hline Viscosity $(\mathrm{cps})$ & 185 \\
\hline Flowing time $\left(25^{\circ} \mathrm{C}, \mathrm{s}\right)$ & $20-40$ \\
\hline Free formaldehyde $\%$ & 0,7 \\
\hline $\begin{array}{c}\text { NH4Cl content }(\max , 1 \%) \\
\text { Gel time }\left(100^{\circ} \mathrm{C}, \mathrm{s}\right)\end{array}$ & $25-30$ \\
\hline Storage time $\left(25^{\circ} \mathrm{C}\right.$, day) & 90 \\
\hline $\mathrm{pH}$ & $7,5-8,5$ \\
\hline
\end{tabular}

Table 2: Raw materials used.

\begin{tabular}{|c|c|c|}
\hline $\begin{array}{c}\text { Board } \\
\text { Type }\end{array}$ & $\begin{array}{c}\text { Corn } \\
\text { Stalks }\end{array}$ & $\begin{array}{c}\text { Poplar } \\
\text { wood }\end{array}$ \\
\hline A & 0 & 100 \\
\hline B & 25 & 75 \\
\hline C & 50 & 50 \\
\hline D & 75 & 25 \\
\hline E & 100 & 0 \\
\hline
\end{tabular}

Raw materials \%

Physical and mechanical properties were evaluated and performed according to ASTM D1037-06 (2004). Tow samples from each board were prepared and used for the static bending to determine modulus of rupture (MOR) and modulus of elasticity (MOE) using the following dimensions: $30 \mathrm{~cm} \times 5 \mathrm{~cm} \times 1 \mathrm{~cm}$, the dimensions for the internal bond testing (IB) were $5 \mathrm{~cm} \times 5 \mathrm{~cm} \times 1 \mathrm{~cm}$. To determine water absorption (WA) and thickness swelling (TS) tests for 2 hours and 24 hours, two samples were taken from each board with dimensions of 5 $\mathrm{cm} \times 10 \mathrm{~cm} \times 1 \mathrm{~cm}$. On computer control electronic universal testing machine (Model: WDW - 200E $\backslash 200 \mathrm{KN} \backslash$ Load accuracy, Class 0,5$)$ the mechanical properties determination tests were completed.

\section{Chemical properties}

The chemical composition of both poplar wood and corn stalk were determined and samples processed following procedures described in TAPPI $257 \mathrm{~cm} 85$ (1985). Holocellulose and alpha cellulose were estimated using the techniques for chloride (Wise and Karl 1962) and TAPPI $203 \mathrm{~cm} 99$ (1999) respectively. The lignin and ash were additional processed by the methods of TAPPI $222 \mathrm{om} 98$ (1998) and TAPPI $211 \mathrm{om} 93$ (1993). Solubility properties were estimated based on alcohol benzene TAPPI $204 \mathrm{~cm} 97$ (1997) cold and hot water TAPPI 207 om 99 (1999) and $1 \%$ NaOH TAPPI 212 om 98 (1998).

\section{Fibers properties}

To determine fiber dimensions the particles of both poplar wood and corn stalks were cut and prepared for maceration process according to the modified franklin method (Franklin 1946). The samples in test tubes were cooked into pulp in the oven set at $60{ }^{\circ} \mathrm{C}$ for $24 \mathrm{~h}$. After washing and rinsing with distilled water and shaking individual fibers were sampled appropriately for measuring. Fibers were spread over a glass slide and they were observed under light microscope according to method described by Jane (1970). A total of 100 fibers were used to measure length, diameter and cell wall for each type. 


\section{Statistical analysis}

Data analysis were performed analysis of variance (SAS 2013) and significant differences between variables were determined by Duncan test at $\mathrm{p}<0,01$ level.

\section{RESULTS AND DISCUSSION}

The mechanical properties of produced particleboard are given in Table 3. The highest value of modulus of rupture MOR of 46,69 MPa was obtained with boards made of wood poplar particles made with $10 \%$ UF (type A, 100 percent). The lowest MOR value of 29,67 MPa was achieved with the produced particleboards with corn stalks (type E, $100 \%$ ). Also, it appears from Table 3 that MOR values of particleboards decreased with increases of corn stalk content in the panels. This result is in accordance with Guler et al. (2016) and Prasetiyo et al. (2019) reporting on the possibilities of utilizing different agriculture residues Kalaycioglu (1992), Goker et al. (1993) and Kalaycioglu and Ors (1993). The addition of corn stalks reduces the MOR of particleboard made of UF.

Table 3: Mechanical properties, test results of ANOVA and Duncan's test of particleboards made from poplar wood and corn stalks particles.

\begin{tabular}{|c|c|c|c|c|c|c|}
\hline \multirow{3}{*}{ Mechanical Properties } & $\begin{array}{c}\text { Board } \\
\text { Type }\end{array}$ & $\begin{array}{c}\text { Mean } \\
(\mathrm{MPa})\end{array}$ & $\begin{array}{c}\text { Standard } \\
\text { Deviation }\end{array}$ & $\begin{array}{c}\text { Standard } \\
\text { Error }\end{array}$ & $\begin{array}{c}\text { Minimum } \\
(\mathrm{MPa})\end{array}$ & $\begin{array}{c}\text { Maximum } \\
(\mathrm{MPa})\end{array}$ \\
\hline \multirow{4}{*}{$\begin{array}{c}\text { MOR } \\
(\mathrm{MPa})\end{array}$} & $\mathrm{A}$ & $46,69 \mathrm{a}^{1}$ & 67,77 & 21,43 & 31,30 & 53,66 \\
\cline { 2 - 7 } & $\mathrm{B}$ & $37,10 \mathrm{~b}$ & 87,62 & 27,71 & 27,86 & 50,31 \\
\cline { 2 - 7 } & $\mathrm{C}$ & $34,54 \mathrm{bc}$ & 65,84 & 20,82 & 23,49 & 45,38 \\
\cline { 2 - 7 } & $\mathrm{D}$ & $32,48 \mathrm{bc}$ & 63,79 & 20,17 & 20,91 & 40,92 \\
\cline { 2 - 7 } & $\mathrm{E}$ & $29,67 \mathrm{c}$ & 73,17 & 23,14 & 16,50 & 37,89 \\
\hline \multirow{5}{*}{$\mathrm{MOE}$} & $\mathrm{A}$ & $1642,61 \mathrm{a}$ & 1788,02 & 565,42 & 1371,36 & 1847,57 \\
\cline { 2 - 7 }$(\mathrm{MPa})$ & $\mathrm{B}$ & $1454,22 \mathrm{~b}$ & 1741,1 & 550,58 & 1140,41 & 1639,57 \\
\cline { 2 - 7 } & $\mathrm{C}$ & $1071,08 \mathrm{c}$ & 1682,26 & 531,98 & 9329 & 1439,02 \\
\cline { 2 - 7 } & $\mathrm{D}$ & $968,70 \mathrm{c}$ & 1415,45 & 447,60 & 914,86 & 1121,39 \\
\cline { 2 - 7 } & $\mathrm{E}$ & $777,07 \mathrm{~d}$ & 1737,47 & 549,44 & 388,83 & 954,28 \\
\hline \multirow{5}{*}{$\begin{array}{c}\mathrm{IB} \\
(\mathrm{MPa})\end{array}$} & $\mathrm{A}$ & $0,491 \mathrm{a}$ & 1,13 & 0,533 & 0,372 & 0,692 \\
\cline { 2 - 7 } & $\mathrm{B}$ & $0,421 \mathrm{~b}$ & 0,793 & 0,251 & 0,355 & 0,570 \\
\cline { 2 - 7 } & $\mathrm{C}$ & $0,381 \mathrm{~b}$ & 0,536 & 0,169 & 0,253 & 0,417 \\
\cline { 2 - 7 } & $\mathrm{D}$ & $0,309 \mathrm{c}$ & 0,516 & 0,163 & 0,219 & 0,380 \\
\cline { 2 - 7 } & $\mathrm{E}$ & $0,240 \mathrm{~d}$ & 0,496 & 0,157 & 0,188 & 0,336 \\
\hline
\end{tabular}

Means with the same letters are not significantly different.

The highest of modulus of elasticity MOE value of 1642,61 MPa was observed in particleboard made using only poplar wood particles type A while the lowest MOE value of 777,07 MPa was noticed for type E panels including $100 \%$ corn stalks particles. The values of MOE showed a similar trend to results of the MOR. MOE values of produced particleboards were decreased with increase of corn stalks content in the panels. Most panel types displayed a significant variation $(\mathrm{p}<0,01)$ in their MOR and MOE properties, as well as the corn particles when used to produce particleboard reduced the MOE values greater than the MOR. These results are in agreement with Guler et al. (2016) and Prasetiyo et al. (2019) and the desired MOE values for multi-purpose particleboards also have been studied and reported as in the literature Goker et al. (1993) and Kalaycioglu and Ors (1993).

Many workers reported that the size of particles influences significantly the produced particleboard, hence the larger size of Particles produced panels has better MOR and MOE than any of those formed from small particles (Kasir 1979, Nazerian et al. 2011, Izekor et al. 2013, Chiman 2015). While in the current study, the poplar particles used are not standardized in the form of shaving residues that are often folded and not identical to the size of the corn stalks, and this folding may have interfered with the particle size and may ultimately 
have yielded different results. This is an explanation why panels produced from poplar particles have better MOR and MOE than those panels produced from pure corn stalks, as well as the lower structural properties of corn stalks. Furthermore the MOR and MOE panels produced from mixed poplar particles and corn stalks such as $\mathrm{B}, \mathrm{C}$ and $\mathrm{D}$ have different mechanical properties of panel types $\mathrm{A}$ and $\mathrm{E}$, the causes of such variation are due to the differences of particles geometry with regard to the influence of interacted amongst kind and particles size with resin content, as well as temperature and press time (Kasir 2006, Malanit et al. 2009, Chiman 2015, Barzani 2015).

Internal bond is a fundamental materials science test in which a sample is subjected to a controlled tension until failure) particleboard made from $100 \%$ poplar wood displayed the maximum IB values of 0,491 MPa while particleboard manufactured from $100 \%$ corn stalks had the minimum IB values of 0,240 MPa. in addition the IB of the particleboard was decreased with increase of corn stalks content in the panels. Study results have also been reported in other reports on corn stalk board (Akgul et al. 2010a, Prasetiyo et al. 2019).

Some studies have been reported that particleboard made utilizing different agricultural residues have lower mechanical properties than those made of wood particle (Bektas et al. 2005, Copur et al. 2007, Nemli et al. 2009, Buyuksari et al. 2010). However, the use of phenolic resins and diverse coatings on the particleboard surfaces can enhance some mechanical properties (Nemli 2003, Nemli et al. 2005).

The dimensional stability of particleboard is affected by different manufacturing factors such as panel density, amount of adhesive and distribution, moisture content, press duration, furnish types and chemical and structural properties of particles (Gertjejansen 1977, Chiman 2015, Akgul et al. 2010a).

The results of water absorption (WA) and thickness swelling (TS) for produced particleboards are listed in Table 4. The highest values of WA $(210,33 \%$ and $243,39 \%)$ and TS $(53,61 \%$ and $61,94 \%)$ were recorded in particleboard type E ( $100 \%$ corn stalks) in a combination for water immersion times of 2 and 24 hours respectively. The mean of WA and TS in percentages for panels differed significantly in the duration of immersion in water $(\mathrm{p}<0,001)$. Ratios of absorption and swelling were increased for all panel types with immersion duration from 2 to $24 \mathrm{~h}$. Thus, increasing of corn stalks ratio in the panels resulted in a higher percentage of WA and TS in produced particleboards utilizing mixture of poplar wood and corn stalks (Figure 1 and Figure 2). From the tests, it is obvious that the majority of swelling in the direction of thickness occurred around test start times up to $2 \mathrm{~h}$, of immersion. This rise relied on the amount of stalks of corn in the panels, which is similar to the results of Guler et al. (2016) and Guler (2016). The results indicated that the panel types E and D for $24 \mathrm{~h}$ was not differing insignificantly in WA and TS. This could be due to corn stalk particles which consist of higher amount of corn stalks and their core panels have softer parenchyma cells and hydroxyl groups that can attract more water because of corn stalk has higher hemicellulose compare to cellulose in wood.

Table 4: Water Absorption (WA) and Thickness Swelling (TS), test results of ANOVA and Duncan's test of particleboards produced from poplar wood and corn stalks particles.

\begin{tabular}{|c|c|c|c|c|c|c|c|}
\hline $\begin{array}{l}\text { Physical } \\
\text { Properties }\end{array}$ & $\begin{array}{l}\text { Board } \\
\text { Type }\end{array}$ & $\begin{array}{l}\text { Soaking time } \\
\text { (minute) }\end{array}$ & $\begin{array}{c}\text { Mean } \\
(\%)\end{array}$ & $\begin{array}{c}\text { Standard } \\
\text { Deviation }\end{array}$ & $\begin{array}{l}\text { Standard } \\
\text { Error }\end{array}$ & $\underset{\mathrm{m}}{\operatorname{Minimu}}$ & $\underset{\mathrm{m}}{\operatorname{Maximu}}$ \\
\hline \multirow{10}{*}{$\begin{array}{c}\text { Water } \\
\text { Absorption } \\
\text { (WA) }\end{array}$} & A & 2 & $97,51 \mathrm{e}$ & 11,15 & 3,53 & 72,36 & 110,42 \\
\hline & $\mathrm{B}$ & 2 & $127,39 d$ & 10,59 & 3,35 & 98,86 & 135,14 \\
\hline & $\mathrm{C}$ & 2 & $145,17 \mathrm{c}$ & 10,74 & 3,39 & 132,72 & 162,33 \\
\hline & D & 2 & $183,91 b$ & 25,19 & 7,97 & 150,61 & 225,94 \\
\hline & $\mathrm{E}$ & 2 & $210,33 a$ & 24,00 & 7,59 & 178,56 & 246,15 \\
\hline & A & 24 & $115,28 \mathrm{~d}$ & 15,30 & 4,84 & 88,42 & 131,25 \\
\hline & $\mathrm{B}$ & 24 & $136,36 \mathrm{c}$ & 17,35 & 5,49 & 110,62 & 159,15 \\
\hline & $\mathrm{C}$ & 24 & $162,17 b$ & 23,66 & 7,48 & 133,26 & 196,74 \\
\hline & $\mathrm{D}$ & 24 & $224,71 a$ & 29,04 & 9,18 & 161,17 & 250,18 \\
\hline & $E$ & 24 & $243,39 a$ & 22,15 & 7,00 & 215,39 & 283,41 \\
\hline \multirow{10}{*}{$\begin{array}{l}\text { Thickness } \\
\text { Swelling } \\
\text { (TS) }\end{array}$} & A & 2 & $43,6 \mathrm{c}$ & 3,58 & 1,13 & 39,16 & 49,15 \\
\hline & $\mathrm{B}$ & 2 & $44,28 c$ & 4,74 & 1,50 & 37,15 & 52,44 \\
\hline & $\mathrm{C}$ & 2 & $48,13 b$ & 3,346 & 1,15 & 43,96 & 56,17 \\
\hline & $\mathrm{D}$ & 2 & $50,57 \mathrm{ab}$ & 3,70 & 1,17 & 44,19 & 56,93 \\
\hline & $E$ & 2 & $53,61 \mathrm{a}$ & 4,82 & 1,52 & 47,56 & 61,02 \\
\hline & A & 24 & $52,38 b$ & 3,41 & 1,08 & 48,73 & 57,19 \\
\hline & B & 24 & $55,52 \mathrm{ab}$ & 4,08 & 1,29 & 50,39 & 60,44 \\
\hline & $\mathrm{C}$ & 24 & $57,19 \mathrm{ab}$ & 4,88 & 1,54 & 49,66 & 64,56 \\
\hline & $\mathrm{D}$ & 24 & $60,71 a$ & 8,82 & 2,79 & 53,57 & 78,39 \\
\hline & $\mathrm{E}$ & 24 & $61,94 a$ & 9,65 & 3,05 & 55,21 & 85,52 \\
\hline
\end{tabular}

Means with the same letters are not significantly different. 
On the other hand, the lowest mean of WA and TS with more poplar wood content (A, B and C types for $2 \mathrm{~h}$ and $24 \mathrm{~h}$ ). probably described by the furnishing consistency, particles properties and adhesive. The similar chemical structure of the corn stalks and poplar wood may explain the result. Corn stalks including a small amount of water-resistant compounds related to lignin and important amount of carbohydrates led to a higher amount of available $\mathrm{OH}$ groups, because of their higher cellulose content in wood compare to higher hemicellulose in stalk. and cellulose is stronger than hemicellulose due to its crystal form and it is more in wood a perennial species.

In general, the high values of some physical properties in this study could be attributed to the lack of wax or other hydrophobic substances not used through laboratory manufacturing of particleboard such as heat treatment, water repellent chemicals like paraffin, phenolic adhesives, acetylating of particles and coating of the particleboard surfaces can enhance the water repellence of the boards (Rowell and Norimoto 1988, Nemli et al. 2005, Guntekin et al. 2008, Buyuksari et al. 2010). WA and TS data obtained in this work are similar to data published by others scientists using different agriculture residues including hemps, sunflowers stalks, cotton stalks, pine wood and teas (Kalaycioglu 1992, Guler 2001, Bektas et al. 2006, Akgul et al. 2010a, Akgul et al. 2010b, Prasetiyo et al. 2019).

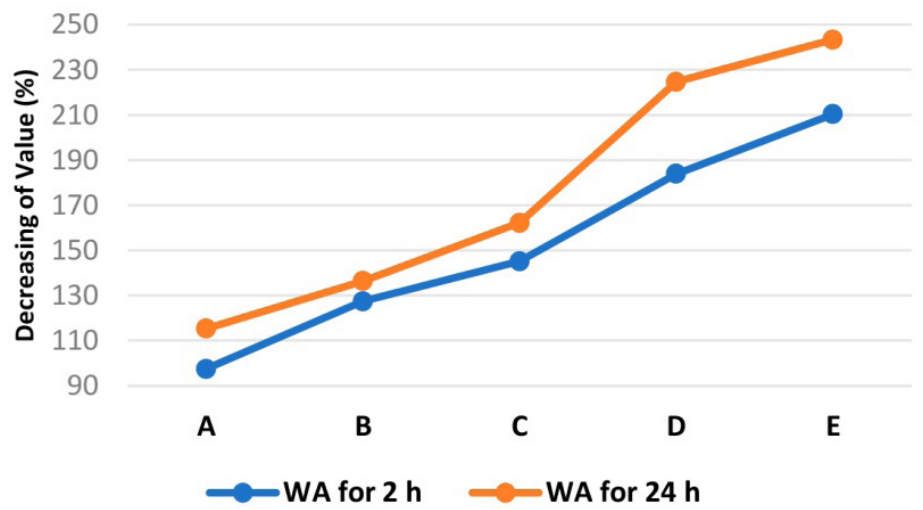

Figure 1: Average values of water absorption (WA) of panel types after 2 and 24 hours of treatment.

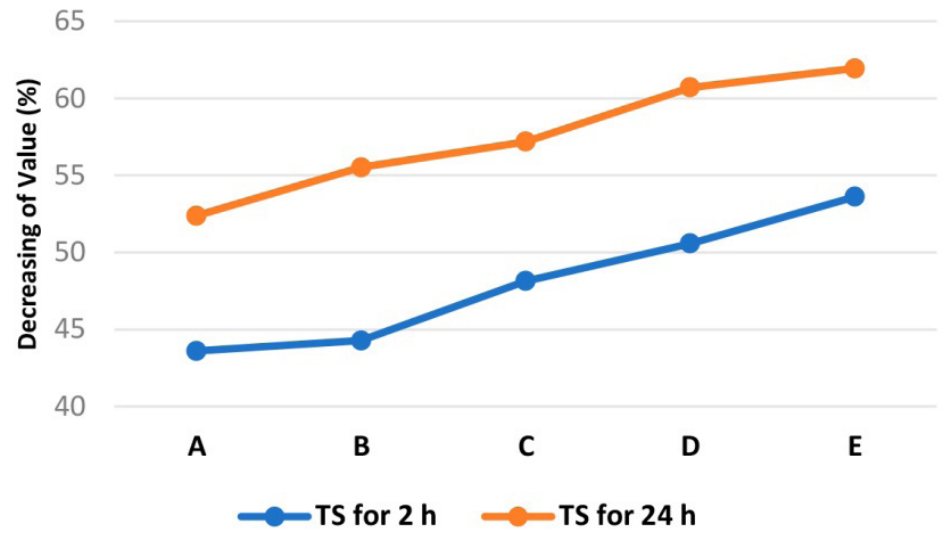

Figure 2: Average values of thickness swelling (TS) of panel types after 2 and 24 hours of treatment. 
Chemical properties of the poplar wood and corn stalks are presented in Table 5. the corn stalks have a have a high content of holocellulose, cellulose and lignin. The chemical interaction between the resin and lignocellulosic materials present in corn stalks have a certain influence on the values of MOE and MOR (Prasetiyo et al. 2019). Chemical composition also impacts the dimensional stability of particleboard, corn stalks with lower water-resistant lignin and increased level of water attractive carbohydrates as mentioned earlier in literature (Akgul et al. 2010a, Akgul et al. 2010b). This finding is in agreement with earlier propositions in literature (Akgul et al. 2010b, Kargarfard and Jahan-Latibari 2011, Guler et al. 2016).

The strength of particleboard is influenced by both fiber geometry and chemical composition of the raw material. Fibers from agro- lignocellulose material is usually weak and the use of longer wood fibers produce stronger panel (Kargarfard and Jahan-Latibari 2011). The average dimensions of particle from corn stalks and poplar wood used to produce in this study particleboard are listed in Table 6 in agreement with data listed by Akgul et al. (2010b) and Kargarfard and Jahan- Latibari (2011).

Table 5: Chemical composition of poplar wood and corn stalks used in manufacture of particleboard.

\begin{tabular}{|c|c|c|c|c|c|c|c|c|}
\hline $\begin{array}{c}\text { Raw } \\
\text { material }\end{array}$ & $\begin{array}{c}\text { Holocellulose } \\
\%\end{array}$ & $\begin{array}{c}\text { Cellulose } \\
\%\end{array}$ & $\begin{array}{c}\text { Lignin } \\
\%\end{array}$ & $\begin{array}{c}\text { Ash } \\
\%\end{array}$ & $\begin{array}{c}\text { Alcohol - } \\
\text { Benzene }\end{array}$ & $\begin{array}{c}1 \% \\
\text { NaOH }\end{array}$ & Hot Water & $\begin{array}{c}\text { Cold } \\
\text { Water }\end{array}$ \\
\hline Poplar wood & 70,2 & 46,73 & 22,56 & 2,19 & 2,73 & 15,22 & 6,20 & 5,19 \\
\hline Corn stalks & 68,19 & 48,37 & 20,42 & 8,76 & 9,54 & 46,6 & 19,06 & 18,31 \\
\hline
\end{tabular}

Table 6: Fiber dimensions of poplar wood and corn stalks used in manufacture of particleboard.

\begin{tabular}{|c|c|c|c|c|}
\hline Raw Material & $\begin{array}{c}\text { Particle length } \\
(\mathrm{mm})\end{array}$ & $\begin{array}{c}\text { particle diameter } \\
(\mu \mathrm{m})\end{array}$ & $\begin{array}{c}\text { Cell wall thickness } \\
(\mu \mathrm{m})\end{array}$ & $\begin{array}{c}\text { Fiber lumen diameter } \\
(\mu \mathrm{m})\end{array}$ \\
\hline Poplar wood & 1,12 & 21,97 & 4,61 & 12,74 \\
\hline Corn stalk & 1,02 & 19,4 & 4,62 & 19,30 \\
\hline
\end{tabular}

\section{CONCLUSIONS}

From the results presented in the text it can be conclude that corn stalks and poplar particles can be utilized at various ratios to produced particleboards which may be utilized in interior applications due to water absorption and thickness swelling resultant. The low internal bond strength value using the adhesive type and level and the type of raw materials (corn stalks) can be upgraded sufficiently by increasing the proportion of wood particles. The results can demonstrate that corn stalks can be considered as an alternative to wood material in the production of particleboards.

\section{REFERENCES}

Akgul, M.; Guler, C.; Copur, Y. 2010a. Certain physical and mechanical properties of medium density fiber boards manufactured from blends of corn (Zea mays indurata Sturt.) stalks and pine (Pinus nigra) wood. Turk J Agric For 34(3): 197-206. http://www.doi.org/10.3906/tar-0902-26

Akgul, M.; Guler, C.; Uner, B. 2010b. Opportunities in utilization of agricultural residues in bio-composite production: corn stalk (Zea mays indurata Sturt) and oak wood (Quercus robur L.) fiber in medium density fiberboard. Afr J Biotechnol 9(32): 5090-5098. https://www.ajol.info/index.php/ajb/article/view/92135

Archanowicz, E.; Kowaluk, G.; Niedzinski, W.; Beer, P. 2013. Properties of particle boards made of biocomponents from fibrous chips for FEM modelling. BioRes 8(4): 6220-6230. https://doi.org/10.15376/ biores.8.4.6220-6230 
ASTM. 2004. Standard Test Methods For Evaluating Properties Of Wood-Base Fiber And Particle Panel Materials ASTM D1037-06 (2004) ASTM. West Conshohocken: PA, USA. https://webstore.ansi.org/standards/astm/astmd103706a

Azubuike, C.P.; Boladale, O.S.; Augustine, O.O. 2012. Pharmacopeial and physicochemical properties of $\alpha$-cellulose and microcrystalline cellulose powders derived from cornstalks. International Journal of Green Pharmacy 6(3):193-198. http://greenpharmacy.info/index.php/ijgp/article/view/260

Barzani, D.F.Y. 2015. Properties of Fiber Composite Boards manufactured from Cartons Waste Chips. MSc. Thesis, Faculty of Agriculture, University of Duhok, Kurdistan Region. Iraq (In English Language).

Bektas, I.; Guler, C.; Kalaycioglu, H. 2006. Manufacturing of Particleboard from Sunflower Stalks (Helianthus annuиs L.) Using Urea-Formaldehyde Resin. Forest Prod J 5(4): 56-60.

Bektas, I.; Guler, C.; Kalaycioglu, H.; Mengeloglu, F.; Nacar, M. 2005. The manufacture of particleboards using sun flowers stalks (Helianthus annuus L.) and poplar wood (Populus alba L.). J Compos Mater 39(5): 467-473. https://doi.org/10.1177/0021998305047098

Biswas, D.; Bose, S.K.; Hossain, M.M. 2011. Physical and mechanical properties of urea formaldehyde bonded particleboard made from bamboo waste. Int J Adhes Adhes 31(2): 84-87. https://doi.org/10.1016/j. ijadhadh.2010.11.006

Buyuksari, U.; Ayrilmis, N.; Avci, E.; Koc, E. 2010. Evaluation of the physical, mechanical properties and formaldehyde emission of particleboard manufactured from waste stone pine (Pinus pinea L.) cones. Bioresour Technol 101(1): 255-259.

https://doi.org/10.1016/j.biortech.2009.08.038

Chiman, A.I. 2015. Manufacturing Particleboard from Different Populus nigra and Pinus sibirica Wood Planer Shavings. MSc. Thesis, Faculty of Agriculture, University of Duhok, Kurdistan Region. Iraq (In English Language).

Copur, Y.; Guler, C.; Akgul, M.; Tascioglu, C. 2007. Some chemical properties of hazelnut husk and its suitability for particleboard production. Build Environ 42: 2568-2572. https://doi.org/10.1016/j. biortech.2009.08.038

Franklin, G. 1946. A rapid method for softening wood for microtome sectioning tropical woods. 88: 3536. https://eurekamag.com/research/013/622/013622801.php

Gertjejansen, R.O. 1977. Properties of Particleboard from Sunflower Stalks and Aspen Planer Shavings. Technical Bulletin 311; Minnesota Agricultural Experiment Station, University of Minnesota: Minneapolis, MN, USA. https://conservancy.umn.edu/handle/11299/109140

Goker, Y.; As, N.; Akbulut, T. 1993. The effects of wood chips having low quality on the properties of particleboards. Proceedings of The First Forestry Meeting, vol. 3, Ankara, Turkey. pp. 392-398

Guler, C. 2001. The Utilization of Cotton Stalks as Raw Material in Particleboard Production, PhD Thesis. Zonguldak Karaelmas University, Zonguldak/Turkey (In English Language).

Guler, C. 2016. Utilization of Some Annual Fiber (Corn and Cotton Stalks) As a Possible Raw Material Environmentally Friendly Panel Production. International Journal of Ecology and Environmental Sciences 5: 1. https://www.semanticscholar.org/paper/Utilization-of-Some-Annual-Fiber-(-Corn-and-Cotton-Guler/84a89b6e1c55af4cffb245feb4bced97d921786f

Guler, C.; Sahin, H.I.; Yeniay, S. 2016. The potential for using corn and stalks as a raw material for production particleboard with industrial wood chips. Wood Research 61(2): 299-306. http://www.centrumdp. sk/wr/201602/13.pdf

Guntekin, E.; Uner, B.; Sahin, H.T.; Karakus, B. 2008. Pepper stalks (Capsicum annuum) as raw material for particleboard manufacturing. J Appl Sci 8(12): 2333-2336. https://doi.org/10.3923/jas.2008.2333.2336

Izekor, D.N.; Amiandamhen, S.O.; Agbarhoaga, O.S. 2013. Effects of geometric particle sizes of wood flour on strength and dimensional properties of wood plastic composites. J Appl Nat Sci 5(1): 194-199. https://doi.org/10.31018/jans.v5i1.305 
Jane, F.W. 1970. The structure of wood. 2nd ed, Adam and Charles Black: London. https://www.abebooks.co.uk/STRUCTURE-WOOD-Revised-2nd-Edition-Jane/1137223517/bd

Kalaycioglu, H. 1992. Utilization of annual plant residues in production of particleboard. IN ORENKO-92, 1st Forest Product Symposium, Trabzon, Turkey, pp 288-292.

Kalaycioglu, H.; Ors, Y. 1993. Technological Properties of Particleboard Produced from Pinus radiata (Pinus pinaster Ait.). Turk J Agric For 17(4): 727-751. https://journals.sagepub.com/doi/ abs/10.1177/0021998305047098

Kalaycioglu, H.; Nemli, G. 2006. Producing composite particleboard from kenaf (Hibiscus cannabinus L.) stalks. Industrial Crops and Products 24(2): 177-180. https://doi.org/10.1016/j.indcrop.2006.03.011

Kargarfard, A.; Jahan-Latibari, A. 2011. The performance of corn and cotton stalks for medium density fiberboard production. Bioresources 6(2): 1147-1157. https://ojs.cnr.ncsu.edu/index.php/BioRes/article/view/ BioRes_06_2_1147_Kargarfard_J_Perform_Corn_Cotton_Stalk_MDF

Kasir, W.A. 1979. Influence of processing variables on the vertical density gradient and properties of particleboard. PhD. Thesis, Dept. of Wood and Paper Sci. North Carolina State Univ.: Raleigh, USA. https://repository.lib.ncsu.edu/handle/1840.20/23/discover

Kasir, W.A. 2006. Using Quercus infectoria Gall Nut Tannin as a binder in particleboards production. Mesopotamia Journal of Agriculture 34(2): 14-22. https://doi.org/10.33899/magrj.2006.26325

Liu, R.; Yu, H.; Huang, Y. 2005. Structure and morphology of cellulose in wheat straw. Cellulose 12(1): 25-34. https://link.springer.com/article/10.1007/s10570-004-0955-8\#article-info

Malanit, P.; Barbu, C.; Fruhwald, A. 2009. The Glu ability and Bonding Quality of an Asian Bamboo (Dendrocalamus asper) for The Production of Composite Lumber. J Trop For Sci 21(4): 361-368. https://www.frim.gov.my/v1/JTFSOnline/jtfs/V21n4/361-368.pdf

Nath, D.C.; Mwchahary, D.D. 2012. Population increase and deforestation: a study in Kokrajhar District of Assam. India. International Journal of Scientific and Research Publication 20(2): 1-12. http://citeseerx.ist. psu.edu/viewdoc/download?doi=10.1.1.375.9187\&rep=rep1\&type=pdf

Nazerian, M.; Ghalehno, M.D.; Shogaiished, M.; Sharifpoor, H.; Taftiyan, M.H. 2011. Properties of three-layer particle board made from wood athel (Tamarix aphylla) and pruning particles of Almond (Amygdalus communis) and pistachio (Pistacia vera). Journal of Basic and Applied Scientific Research 1(8): 837-843. https://www.textroad.com/pdf/JBASR/J.\%20Basic.\%20Appl.\%20Sci.\%20Res.,\%201(8)837-843,\%202011. pdf

Nemli, G. 2003. Effects of Coating Materials Process Parameters on the Technological Properties of Particleboard. PhD. Thesis, Karadeniz Teknik University, Trabzon, Turkey.

Nemli, G.; Demirel, S.; Gumuskaya, E.; Aslan, M.; Acar, C. 2009. Feasibility of incorporating waste grass clippings (Lolium perenne L.) in particleboard composites. J Waste Manag 29: 1129-1131. https://doi.org/10.1016/j.wasman.2008.07.011

Nemli, G.; Ors, Y.; Kalaycioglu, H. 2005. The choosing of suitable decorative surface coating material types for interior end use applications of particleboard. Construction and Building Materials 19: 307-312. https://doi.org/10.1016/j.conbuildmat.2004.07.015

Prasetiyo, K.W.; Astari, L.; Syamani, F.A.; Subyakto. 2019. Physical and Mechanical properties of urea formaldehyde and phenol formaldehyde-bonded particleboard made from corn stalk. IOP Conference Series: Earth and Environmental Science 374(1): 012050. https://doi.org/10.1088/1755-1315/374/1/012050

Rowell, R.M. 1995. A New Generation of Composite Materials from Agro-Based Fiber. In Proceedings of the 3rd International Conference on Frontiers of Polymers and Advanced Materials, Kuala Lumpur, ML, January 16-20, pp. 659-665. https://doi.org/10.1007/978-1-4899-0502-4_68

Rowell, R.M.; Norimoto, M. 1988. Dimensional stability of bamboo particleboards made from acetylated particles. Mokuzai Gakkaishi 34(7): 627-629. https://www.fpl.fs.fed.us/documnts/pdf1988/rowel88d.pdf 
Rowell, R.M.; Han, J.S.; Rowell, J.S. 2000. Characterization and factors effecting fiber properties. Natural Polymers and Agrofibers Composites: 115-135. https://www.fpl.fs.fed.us/documnts/pdf2000/rowel00b.pdf

SAS. 2013. The SAS System for Windows, Release 9.4. Statistical Analysis Systems Institute: Cary, NC, USA. 556p. https://www.scirp.org/(S(351jmbntvnsjt1aadkposzje))/reference/ReferencesPapers.aspx?ReferenceID $=2019885$

Suleiman, I.Y.; Aigbodion, V.S.; Shuaibu, L.; Shangalo, M. 2013. Development of eco-friendly particleboard composites using rice husk particle and gum Arabic. Journal of Materials Science and Engineering with Advanced Technology 7(1): 75-91.

TAPPI. 1985. Sampling and preparing wood for analysis. TAPPI $257 \mathrm{~cm} \mathrm{85.} \mathrm{TAPPI:} \mathrm{Atlanta,} \mathrm{GA,} \mathrm{USA.}$ https://ipstesting.com/find-a-test/tappi-test-methods/

TAPPI. 1993. Ash in wood and pulp. TAPPI 211 om 93. TAPPI: Atlanta, GA, USA. https://ipstesting.com/ find-a-test/tappi-test-methods/

TAPPI. 1997. Solvent extractives of wood and pulp. TAPPI $204 \mathrm{~cm}$ 97. TAPPI: Atlanta, GA, USA. https://ipstesting.com/find-a-test/tappi-test-methods/

TAPPI. 1998. One percent sodium hydroxide solubility of wood and pulp. TAPPI 212 om 98. TAPPI: Atlanta, GA, USA. https://ipstesting.com/find-a-test/tappi-test-methods/

TAPPI. 1998. Acid-insoluble lignin in wood and pulp. TAPPI 222 om 98. TAPPI: Atlanta, GA, USA. https://ipstesting.com/find-a-test/tappi-test-methods/

TAPPI. 1999. Alpha- Beta- and Gamma-Cellulose in Pulp. TAPPI $203 \mathrm{~cm}$ 99. TAPPI: Atlanta, GA, USA. https://ipstesting.com/find-a-test/tappi-test-methods/

TAPPI. 1999. Water solubility of wood and pulp. TAPPI 207 om 99. TAPPI: Atlanta, GA, USA. https://ipstesting.com/find-a-test/tappi-test-methods/

Wang, D.; Sun, XS. 2002. Low density particleboard from wheat straw and corn pith. Industrial Crops and Products 15(1): 47-50. https://doi.org/10.1016/S0926-6690(01)00094-2

Wise, L.E.; Karl, H.L. 1962. Cellulose and hemicellulose in pulp and paper science and technology. In: Earl, Libby C. (Ed.) Vol. 1. Mc Graw Hill Book Co: New York.

Zhang, L.; Hu, Y. 2014. Novel lignocellulosic hybrid particleboard composites made from rice straws and coir fibers. Mater Des 55: 19-26. https://doi.org/10.1016/j.matdes.2013.09.066 